\title{
Surviving Amidst COVID-19 Economic Impacts in Tanzania: Learning from Porters and Guides at Kilimanjaro National Park
}

\author{
Vitales Joel Kabonda \\ College of African Wildlife Management, Tanzania
}

\begin{abstract}
In Tanzania, tourism industry employed about one million people which is 11.2 percent of total work force in Tanzania. This is due to the fact that Tanzanian is having many distinct natural features that attract tourists such as Kilimanjaro Mountain which is the roof of Africa. Among those one million jobs in tourism industry, porters and guides of Mount Kilimanjaro are included. COVID-19 has impacted tourism industry negatively to the point that the industry was shut down in 2020 and all jobs and employment were cut off. Among the most affected groups are porters and guides in Mount Kilimanjaro their jobs are temporary and depend on seasons. This study sought to explore the economic impact caused by COVID-19 pandemic to porters and guides and the strategies that they used to survive amidst the difficult period of COVID-19 to make a living and fulfill their family's basic needs. Learning from these porters and guides the study revealed the major negative economic impact they faced was reduction in the individual and family income caused by decrease in the number of visitors due to COVID-19 pandemic. The study further revealed that, there are number of aspects that made them survive amidst COVID-19 pandemic such personal saving, gifts and grants from once served tourists, subsistence allowances from their employers and engaging in other income generating activities such as subsistence small scale farming, sedentary livestock keeping, seeking for alternative employment and engaging in small business and entrepreneurship. The study recommends that porters and guides have to develop some plans that can make them well prepared to cope up with the negative economic impacts that will be caused by any other disasters to the industry in future time.
\end{abstract}

Keywords: COVID-19, Economic Impacts, Porters, Guides

Corresponding author: Vitales Joel Kabonda; E-mail: vitales.kabonda@mwekawildlife.ac.tz DOI: https://doi.org/10.37227/ITHJ-2021-9-316

\section{Introduction}

Tourism and travel industry is perhaps the largest and fastest growing business in the world; the industry's annual growth rate is 4.6 percents over recent decades (Frolova, 2019; Tovmasyan, 2019). For seven years consecutively, it has outperformed the world economic growth by three percent (Sofronov, 2018a; Sofronov, 2018b; Sofronov, 2018c). The sector is well known for its ability to provide a considerable number of employment opportunities directly and indirectly. For instance in 2017, the sector employed 313 million people directly and contributed about $10 \%$ of global Gross Domestic Product (GDP) (World Tourism Organization, 2020). Recently World Travel and Tourism Council 
(WTTC) found that travel and tourism sector supported one out of every ten jobs globally, and it accounts for one in any five new employment opportunities created in the last five years in a row (Mwamwaja \& Mlozi, 2020).

In Africa, travel and tourism sector accounts for 8.5 percent of the whole continent's GDP. This equals to \$ 194.2 Billion of total continent earning (Costa, 2018). Mwamwaja (2020) contended that, Africa is the second tourist region growing faster in the world behind United States of America; the growth rate is 3.9 percents for recent years.

According to World Travel and Tourism Council (2020) the tourism industry in Tanzania has kept on growing for years. It has a remarkable contribution in the country's GDP accounting to 17.5 percent of total GDP which was about \$2 billion in 2016. The contribution of the sector kept on rising. For instance, in 2018, the sector has contributed about $\$ 2.43$ Billion contributed by the general increase in the number of arrivals in Tanzania (Gwalema, 2019). According to the Ministry of Natural Resources and Tourism, the international arrivals raised to $1,527,230$ million in 2019. The revenue generated in that year accounted to TZS 5 billion (MNRT, 2020). The sector employed about over a million people which is 11.2 percent of the total workforce in the country (Grobelna \& Skrzeszewska, 2019). Melubo \& Kisasembe (2020) contended that, Tanzania was ranked $8^{\text {in }}$ in the African region and $95^{\text {th }}$ in the world by Travel and Tourism competitive index 2019 report. This means that Tanzania has all the condition and power to attract more international arrivals (Melubo \& Kisasembe, 2020).

In an attempt to improve tourism performance in Tanzania, the government through the ministry responsible for Natural Resources and Tourism has adopted and created many initiatives to increase international arrivals. For instance, in 2017 the fourth annual Diaspora homecoming conference was held in Zanzibar. The objective of the conference was to bring together Tanzanians living abroad to exchange and share ideas about investment opportunities in Tanzania which include investing in travel and tourism industry (Bank of Tanzania, 2018). In addition to that, the government has been struggling to development new brand for Tanzania whereby National Branding committee was established in December 2017 to execute the responsibility of branding Tanzania internationally. The campaign has been effective and successful as up to 2019 before COVID-19 the number of visitors increased rapidly. Ministry of Natural Resources and Tourism (MNRT) has made a review of the outdated tourism policy of 1999 to address and tackle the challenges and obstacles that face the tourism growth efforts and find a way forward to improve tourism performances in order, the ministry re-examined tourism development strategies and approaches as shown in the National Tourism Policy of 2018. It aimed at ensuring that the sector sustains in different problems and changes facing the industry time to time, but also creating conducive environment for investing, improving infrastructures for transportation like air, road and railways, tourism product diversification from commonly known wildlife based tourism to other form of tourism like beach tourism and cultural tourism, capacity and awareness building to local communities which can boost domestic tourism and other similar tourism activities . All these efforts in some times have been proved to be effective as the number of tourists have been rising as well as the tourism earning for several years until 2019.

The efforts have made tourism sector a backbone to many people's economy in Northern tourism circuit in Tanzania. The northern tourism circuit is the leading circuit in Tanzania with many tourists' attractions including large number of national parks (Tanzania Conference Directory Report, 2012). A number of people have been employed and are benefiting directly and indirectly through tourism. Most of the individuals have 
been employed directly as safari guides, mountain guides, cooks, porters, tour organizers, tour consultants, and travel agencies while others own tour operator companies (Mangwangi, 2015). Others have been employed directly in those facilities providing hospitality services to tourists like hotels, lodges restaurants and transportation services. Others have employed themselves in selling goods and services to tourists directly such as fruit vendors, food vendors and gifts shops (Mangwangi, 2015). In Kilimanjaro, national park, there found a very famous free standing mountain, the second highest in the world and first in Africa, Mount Kilimanjaro. A number of international tourists usually wish and conduct an expedition to this roof Africa. Therefore, there are a number of people employed directly to take and escort these visitors to the top. They are famously known as porters and mountain guides who make their living through taking tourists to these beautiful adventures (Melubo \& Buzinde, 2016).

However, things turned upside down at the end of 2019. There has been a tremendous operational, commercial and financial crisis in tourism and hospitality industry in 2019 (Kasese, 2019; Paper, 2020). This has crisis has been caused the deadly novel corona virus named COVID-19 pandemic (Nyaruwata \& Mbasera, 2021; Karim, Haque, Anis \& Ulfy, 2020; Horaira, 2021). It has a had an overwhelm impacts on the global tourism and hospitality industry (Smart et al., 2021). It damaged both, tourist's destinations and tourist's source markets, the commercial and operation activities came to an end (Yang et al., 2020;Paper, 2020). According to Mwamwaja (2020) players in all touristic sectors providing services to tourists stopped providing services for unknown period of time which resulted an immediate cut off of revenue streams.

Globally, the COVID-19 pandemic has had a substantial and detrimental influence on many tourism businesses. The number of international arrivals declined substantially worldwide. For instance, Malaysia's tourism business was affected whereby travellers from all over their source market in the world cancelled and postponed their vacations plans to Malaysia due to worries of the virus. Malaysian government imposed travel restrictions and bans which resulted in the decline of number of arrivals. Many countries such as Malaysian are employing various strategies to boost domestic tourism (Foo et al., 2020a).

Nepal also suffered the consequences; jobs in hotels and tourism industry were cut off. Almost about 200,000 people who were directly employed in hotels, restaurants, hiking, airlines, mountaineering and other subsectors in tourism industry remain jobless (Asian Development Bank, 2019; Ulak, 2020). The recovery of international tourism after pandemic is expected first with some specific regions like European regions, but domestic tourism is expected to recover more quickly. Tourism stakeholders from different country have urged their government to provide relief packages so that they can at-least maintain their businesses and jobs (Ulak, 2020).

In Malaysia's tourism industry, the COVID-19 pandemic had also significant impacts. Tourists from all over the world cancelled their bookings and others delayed travel plans to Malaysia due to big worries of the corona virus. Malaysian government imposed travel bans and restrictions which led to decrease in the number of international arrivals, although the government has put forward the strategies to promote domestic tourism (Foo et al., 2020b).

The United States of America (USA) was also hardly hit by COVID-19, the study was done to explore the impacts in tourism industry and examine how lodging industry in USA has been able to cope with the impacts of COVID-19. The findings revealed that I dealing with business challenges caused by COVID-19 hotels in Oklahoma have developed a framework of their coping strategies for effectiveness such enhancing hotels financial 
stabilities such as saving techniques which include monitoring payrolls, redundant positions that add operational expenses were removed, dismissing some of the employees and conducting market segmentations and lastly that the customers and employees health and safety was at a front line (Smart et al., 2021b)

In African continent, South Africa is among the most affected destinations in Africa by COVID-19 pandemic. People were asked to rethink both, within and outside the tourism industry to cope with the crisis by having a focus on local dimensions of their space such as making a link between tourism and host communities as a strategy to survive when there are no visitors (Rogerson \& Rogerson, 2020)

The study conducted in Rwanda found that COVID-19 had a negative effect on MICE tourism, the government of Rwanda imposed travel restrictions which caused international tourists to cancel all commercial air travel. Tour operators and tourism related businesses lost incomes, and there were a massive cut off of employments related to travel and tourism (Celestin, 2020). The study advised that operators in MICE tourism should demonstrate strong creativity, innovation and resilience skills. This can help to rebuild a sustainable tourism industry. COVID-19 outbreak can be used in improving crisis management strategies and strengthen international and domestic tourism operations and coordination mechanisms (Celestin, 2020).

Tanzania cannot be left behind as it is not an isolated island. The impact of COVID-19 pandemic on tourism in Tanzania has become more evident in 2020. International airlines were forced to stop operating in the country (Mwamwaja, 2020). Professor Adlof Mkenda, former Permanent Secretary of Tanzania's Ministry of Natural Resources and Tourism reported that tourism is among the sectors that have been mostly affected. There were flight cancellations and bans into and outside the country, closure of hotels, lodges, restaurant and other businesses depending on tourism industry. A relatively big number of jobs have been lost due to tourism market downturn including those of porters and guides and Kilimanjaro Mountain (Mwamwaja, 2020). Porters and guides have suffered the economic impact of COVID-19 but little is known on how porters and tour guides who guides and escort visitors to the roof of Africa have managed to survive amidst economic impact of COVID-19 pandemic.

Many studies have been conducted such as Kunwar (2021), Celestin (2020), Tiwari et al. (2020), Mwamwaja (2020), Gil-Alana \& Poza (2020), Hafsa (2020), Deb \& Nafi (2021), Shivakoti, (2021), NAIEM (2021), Shah et al. (2021), Kvirkvelia \& Tsitsagi (2021) and many other, have concentrated much on exploring the impacts of COVID-19 in travel and tourism industry in different countries. No any known study conducted that explored the negative economic impact of COVID-19 pandemic to porters and mountain guides in Mount Kilimanjaro. Therefore, this study intends to find out how porters and mountain guides have been able to cope and survive amidst COVID-19 pandemic economic impact.

\section{Research Methods}

The study was conducted at Kilimanjaro National Park (KINAPA) located at northern Tanzania in the north of Moshi Town, it borders Kenya. It is within Kilimanjaro National Park where the second highest free standing mountain in the world is found. Kilimanjaro Mountain is one of the major tourist attractions found in the park. The elevation of the mountain is about 5890 Meters above sea level that make it the first highest Mountain in Africa famously known as the roof of Africa. A good number of tourists come from different countries in the world to climb the mountain (Melubo, 2015). The mountain has ascending and descending routes where the ascending routes outnumber the descending 
routes. It has five popular ascending routes which are Marangu, Machame, Umbwe, Rongai, and West Kilimanjaro but also two popular descending routes which are Mweka and Marangu. Kilimanjaro Mountain is chosen because of its beauty as a symbol of Tanzania and one of Africa's Seven Wonders of the World (Melubo, 2015). In comparison to other mountains in the region, Kilimanjaro Mountain accommodates a relatively large number of mountain porters and mountain guides, but also many porters and guides association offices are located nearby this mountain around Moshi Municipality (Melubo \& Buzinde, 2016)

Now to get an understanding of the ways that porters and guides used to survive the COVID-19 pandemic economic impact, it was appropriate to consider conducting a qualitative study (Melubo \& Kisasembe, 2020). Interviews were conducted with guides and porters between January to June 2021 before the reopening of the borders for travelling(Cleth, 2015). At that time, very few visitors climbed the mountain, and mostly domestic tourists. Therefore, few of the interviewed respondents were found when ascending or descending in all these routes. Majority were reached through phones as they were not found in these routes because there were no visitors.

A semi-structured interview was employed in this study. A semi-structured interview helped a researcher in gathering the required valid and reliable data to address the research questions and objectives, respondents were able and ready to provide clarification as needed (Ratcliffe, 2002; Robson, 2002). The interview method was carried out with tour guides, porters, and the officers from associations of tour guides and porters to get in-depth views about the economic impacts of COVID-19 pandemic to porters and guides

The interview conducted was in conversational style as supported by (Melubo \& Kisasembe, 2020). After getting some few porters and guides at the entrance gates and interviewed them, the researcher asked them to provide contacts of guides and porters who can best provide information about COVID-19 Impacts. And in total 100 respondents were interviewed. The questions which were guiding the study included, what are the economic impacts of COVID-19 pandemic to porters and guides, and how did porters and guides managed to live and sustain the COVID-19 pandemic economic impacts. Thematic analysis was used to analyze the data and themes were developed after analysis. Themes developed from the analysis of the data collected are discussed in the next part.

\section{Results and Discussion}

The study was guided by two major questions, although some follow up questions were asked to get more clarifications on the basic answer. In all 100 respondents interviewed, 95\% which equals to 95 respondents are males and only $5 \%$ of the respondents were females. The number males are bigger because traditional ground, that tourism operations and tourism industry generally is dominated by males but also the nature of work itself, it is very difficult to be performed by females. From the two questions guided the study which includes (i) what are the economic impacts of COVID-19 pandemic to porters and guides? (ii) How did porters and guides managed to live and sustain amidst COVID-19 pandemic economic impacts. The following are findings from the study.

\section{Economic Impacts of COVID-19 Pandemic to Porters and Guides from Kilimanjaro Mountain}

When the respondents were asked about economic impacts of COVID-19 pandemic outbreak that prevented and blocked international arrivals to Tanzania, majority said that 
they were hardly hit negatively economically by this pandemic. This was because there were no any international arrivals to Tanzania from December 2019 to at least may, 2021. Most of the Tanzania tourist's source market banned internationals travels to and from their countries. Bookings which were made to tour operators were all cancelled and thus made porters and guides to stay jobless for the whole period of the pandemic (Sharma et al., 2021). This is evident in many countries in the world as reported by (Noorashid \& Chin, 2021) that COVID-19 pandemic has heavily hit and impacted travel and tourism industry globally as well as livelihood of people and public services.

The respondents were also asked to name and explain the negative economic impact caused by the pandemic, one major impact mentioned is reduction of income attributed by reduction in the number of trips. The impact is discussed below:

\section{Reduction in Individual and Households Income}

Reduction of income in the sense of porters and guides means that the total individual and households earning per months has declined. Most of these porters and guides family depended much on their family members who are porters and guides to climb a mountain and earn a living. Therefore, cutting down of their jobs due to COVID-19 pandemic impact to the tourism industry has hardly affected the income. The study further revealed that the average income of a guide before COVID-19 pandemic was between 1.5 Million to 2 Million Tanzanian shillings and that of a porter was between 0.5 Million to 1 Million per months. Whereas the average number of trips per months were 2 to 4 trips. But due to COVID-19 pandemic it has resulted to zero number of trips to zero earning per months for the whole period of severe COVID-19 pandemic outbreak. One of the respondents said:

\footnotetext{
"It is so sad that, I can see the beauty of the mountain, but I can longer take visitors there because no one is coming. COVID-19 has made us poor to the extent that sometimes we do fail even to pays for bills and feed our families. It is just because we depended much on this mountain without having a prior thought of the future uncertainty that could hardly impact our income. But I hope things will turn out normal in the near future"

"I thought it's a mere dream, seeing from media and news that a good number of people are dying just because of the virus, but I did not see anyone dying in our premises at first, it came into my attention now when I received a notification from my supervisor that all trips scheduled in the near future have been cancelled because many countries have banned all international travels. Therefore, let's stay home and wait for what the future holds about our destiny."
}

Generally, Most of People, Mountain guides and porters inclusive are have relatively suffered from COVID-19 pandemic negative economic impact because they did not expect it and it was unforeseen, therefore they were not prepared. Mostly they rely on mountain as their source of income (Peaty, 2010). The findings of the study have been supported by (Madani et al., 2020; Abbas et al., 2021) in their studies, they contended that, COVID-19 has increased life difficulties in most of the families. Quarantines are taking place everywhere in the world and people in many countries are not allowed to get out of their homes and go for work for a living. That made the families incomes to relatively decrease (Kang, 2021). It has resulted into global economic challenges that have affected global economic and individual incomes worldwide. Individual are struggling to survive amidst COVID-19 pandemic impact in economic sectors such as tourism (Abbas et al., 2021; Yuniti et al., 2020) 


\title{
Strategies to Survive and Sustain the COVID-19 Pandemic Economic Impact
}

Respondents were asked on how they have been able to survive (make living) the economic impact of COVID-19 pandemic, because their jobs which they depended much on were cut by the outbreak of Covi-19 keeping in mind that they did not prepare themselves as they did not know that there will be an outbreak in 2020. The aspects emerged during interview were analyzed thematically and the themes (Strategies) were grouped into four categories.

\section{Personal Saving}

The study found that, porters and guides had saved part of their income that they were making before COVID-19 Pandemic. Most of them had the saving habit that they do not consume all what they make in a month. After meeting all necessary basic needs and other needs, the remaining part of the income is saved. All of them had bank accounts in different banks such National Microfinance Bank (NMB), Kilimanjaro Cooperative Bank (KCB), CRDB bank and national bank of commerce which have branches in Moshi and Arusha. This is what has helped them most survive and sustain the economic impact of COVID-19 pandemic until when the tourism industry was reopened on May 2021. In economic perspective there are three motives of holding money, the transaction motive, speculative motive and precautionary motive (Potì et al., 2020). The precautionary motive requires a person to hold money (save) just to address some un-forecasted future problems (Aizenman et al., 2015). Therefore, in this perspective of porters and tour guides, the precautionary motive of holding made holds true as they have been able to feed their families and cover some other needs through saving. They added that when the industry is full operation, the average saving of a guide per month could be 300,000 to 500,000 and that of a porter could be 100,000 to 200,0000 . One of the guides said:

\footnotetext{
"I am not a permanent employee of this company; I am paid whenever climb the mountain and the rate is paid per day. A trip may take up to seven days depending on the root. Now because I am sometimes not that next months the company will have visitors, I save some amount of money that I get per trip so that when I don't get a chance to climb in the coming month, my family could still get the basic needs."
}

The saving habit has not been attributed by absence of visitors that make the trips to be minimal within a month, but has been just because the mountain climbing needs a person who is health and fatigue; there it's impossible for the climbers to anticipate their health status in sometimes to come. If someone fall sick and he/she cannot climb then, he can use the saving now at the time he is sick. One of the porters said:

\begin{abstract}
"The wage system is based on the number of days you climb. If you don't climb you don't get paid. Therefore, it is not that all the time a person will be healthier to climb, a person may fall sick fail to climb, that what will that person feed the family while no trip no money, that is what made me think of having a bank account to save some amount for future."
\end{abstract}

Other motive that made them saves part of their income for their family development projects. They have been saving for the purchase of real estate like purchasing plots for house constructions. Purchasing assets like motor vehicles and motor cycles. But in the course of saving to accomplish their goals, it's where the COVID-19 pandemic emerged and the industry shut down. The money helped them to survive when they were jobless during COVID-19 pandemic outbreak. One of the respondents said: 


\begin{abstract}
"I had a plan to purchase a land plot to start constructing my living house. I started to save part of my income from climbing mountain to accomplish the goal in early 2019 hoping that at the end of 2020 I will have already accomplished it. When it reached early 2020 there was a total shutdown of the industry that made us jobless. Therefore, I used the saving that was in my bank account just for feeding my family and other basic needs."
\end{abstract}

The findings are in line with that of (Hoque, 2020; Potì et al., 2020) who found that in most cases people are saving money for unforeseen immergences and others for investment and developments projects. It is important to make sure that in any income that one getting, has to save for future unforeseen problems. Some of these respondents could be in a great trouble if at all there were not having some saving money.

\title{
Subsistence Allowance from Employers
}

Study revealed that majority also of the porters and guides at Kilimanjaro Mountain were given some amount of money as subsistence allowance to enhance their living due to COVID-19 economic impacts. The amount of money given to porters and guides were varying from one tour Operator Company to the other. The average amount ranged from 50,000 to 100,000 for porters and 100,000 to 200,000 for guides. The money was given to them to help them feed their families at the time of pandemic where there were no visitors to the extent that they cannot make any living out of climbing. One of the reason mentioned as to why they think are the reasons that made companies that they work with to provide such allowance during COVID-19 pandemic while they are not permanent employees is that, the company wants to keep them so that they maintain the spirit of liking the mountain hiking job so that when the industry is opened they can still be ready to take visitors to the roof of Africa. One respondent argued that:

\footnotetext{
"Companies are giving us the allowance in order to keep us attached to the company and maintain the bond that we created throughout. When they live us ideal, it's very possible for us to think that they do not value us while we are the one helping them to make a lot of money. It is also possible for us to think of doing other businesses that can assure us that we can earn income through out and abandon that of mountain climbing."
}

Others were not given the allowance in cash, instead they were given in form of goods particularly food. They were asked about the size of the family in terms of number of family members so that the company can estimate the amount of food in Kilogram needed for whole months. Then the company provides such food. One of the respondents said:

\footnotetext{
"In my company that I am working with, we are only given food that is enough for your family for the whole month. We are given depending on the size of your households. What the company provides is kilograms of rice and beans. With regard to other needs like house rent, they don't real bother themselves about that."
}

The findings concur with that of (Anitha, 2014) who commented that, in order for employees to build a passion with the company and create and strong bond, it's good for them to be given incentives like alliances, bonuses as well as material goods (Francis Mugisha \& Mwende Kajungu, 2015). But most importantly helping them at their difficultly times. This will make them work efficiently and believe in the company they are working with. 


\title{
Gifts and Grants from Tourists (Clients) they once Served
}

The study found that, porters and guides also survived and sustained through gifts and grants in terms of money which they received from their clients (Tourists) they climbed with to the roof of Africa (Mt. Kilimajaro). It is well known in marketing that if you can help the customer meet his/her expectation, he/she will be highly satisfied, and he/she will not forget the service provider. When a tourist is satisfied, what he can actually do is to provide gifts to a service provider. According to (Galak et al., 2016) a gift is anything including amount of money given willingly to service provider by a customer to show appreciation of the good services provided. Porters and guides were given tips from highly satisfied tourists who climbed the mountain, but above all the porters and guides maintain contact with these tourists even when they go back to their home countries. A good relationship is maintained and it is through this relationship that porters and guides can receive gifts and grants from these tourists. One of the mountain guides said:

\begin{abstract}
"One day, I was at home watching news. I received a WhatsApp call; it was my friend Yulk from Norway who I once took him to the highest peak in Africa, Uhuru peak. He asked me of how COVID-19 has affected the tourism industry and our job. I explained to him how serious the issue was, he told me that he could send me $\$ 300$ just to help me in this difficult time, I was so grateful that after received the money."
\end{abstract}

\section{Engaging in other Income Generating Activities}

Another strategy revealed by the study concerning how the porters and guides have managed to survive the COVID-19 pandemic economic impact is through engaging in other income generating activities (Ulak, 2020). Few had these projects and activities but many had no these activities before COVID-19 pandemic. But after been hit by COVID-19 economic impact, many thought of starting to engage in these other incomes generating activities. Activities mentioned are many, but the researcher analyzed and grouped them into five categories.

\section{Engaging is Small Scale Agriculture}

The study found that, mostly porters and guides also engaged themselves in small scale agriculture. Small scale agriculture is the type of agriculture which involves producing food crops for personal consumptions (Burlingame et al., 2019). According to the interview conducted with these porters and guides, majority did not engage themselves in small scale agriculture before COVID-19 pandemic, only few had engaged before. But now because COVID-19 has cut off their jobs in tourism industry, they decided to turn into small scale agriculture which is subsistence. The average size of the land that an individual owns is 1 to 2 acres of land. Areas where they actually carried out this subsistence farming is Hai district, Siha District and Rombo district in Kilimanjaro region because these areas are having enough rainfall and big sizes of farm lands (Soini, 2005). The crops they mainly cultivate include horticultural crops such as vegetables, and vegetable fruits, but also food crops such as maize and potatoes. Few of the respondents are carrying the subsistence farming in Arusha region. One of the respondents said:

"I was born and raised in a peasant family, so I am not bothered much to turn into small scale agriculture for the survival of the family just because the industry is shut down"

"My parents have been peasants since then, so it is something that we were raised with. I cannot let my family die of hunger just because the tourism industry is shaken by COVID-19 and no jobs." 
Sometimes in trying to make a living, one should not be selective of different kind of jobs. One is supposed to have varieties of skills to enable him to do varieties of activities as commented by Krieger et al., (2018) in case of any problem like COVID-19 that has caused the shut-down of tourism industry. Graeub et al., (2016)commented that agriculture is the backbone of many families' economy. In Tanzania about 70 percent of people are agriculturalists (Kimaro, 2014). It is also a backbone of Tanzanian economy as it contributes about 60 percent of export earnings (Kimaro, 2014).

\section{Engaging in Livestock Keeping}

Just like small scale agriculture, porters and guides also engage in livestock keeping to make their living out mountain climbing. The kind of livestock keeping that they practice is sedentary livestock keeping or zero grazing. According to Weber and Horst, (2011)sedentary livestock keeping is a practice of keeping kettles in one place permanently. It involves keeping few kettles economically. What the respondents keeps most in their homes is cows and goats. The benefit that they get by keeping kettles is selling milk which gives them money. The money also helps them in getting the basic needs such as food for the family. It's a kind also of a self employment, and in this kind of activities no much effort is needed except taking care of the kettles by supplying them with food and healthcare. One respondent said:

"I have two cows in my home, I use modern ways to keep them that gives me higher yields such as milk, I sell the milk to hotels and restaurants and use the money to buy basic needs for my family."

As in agriculture, livestock also take part in many economies of the families in Tanzania. Many families keep kettle and they benefit directly from the kettles kept. There are pastoral societies whose main economic activity is livestock keeping. They keep large heads of kettle and that is where the family income comes from.

\section{Seeking for Alternative Employment Opportunities}

Another strategy for survival of COVID-19 economic impact that was revealed by this study is to look for alternative employment opportunities in other sectors. Guides and porters looked for opportunities to be employed in other industries such manufacturing industry. After the industry was shut down they went areas such Arusha, Dar es Salam, Moshi-Kilimanjaro, Tanga and Mwanza to look for other opportunities in other sectors such as manufacturing. Some other porters and guides were having other skills that could help them be employed in other sectors. For instance, one of the interviewed guides was having sales and marketing skills, therefore the respondent then went to look for alternative employment and got employed in Coca-Cola industry as a sales person. The employment is permanent and pensionable that the respondent does not think of going back to tourism industry even when things turn out better in the future. Others have been employed in retail and wholesale shops, as well as supermarkets. One of the respondents said:

\footnotetext{
"Before being a guide, I had a bachelor degree in marketing management, later I built an interest on the tourism industry and I went for diploma in tourism and tour guiding that made me a mountain guide. Therefore, after this COVID-19 Pandemic hit the industry cut jobs offs, I decided to look for another employment by using my degree in sales and marketing."
}

The problem existing with the alternative employment they got is low wages compared to being a porter or a guide. As noted before, when the tourism industry is fully operational 
the average earning of a porter ranges between 0.5 to 1 million Tanzanian Shillings per month, but with the alternative employment, the salary is 400,000 to 500,000 Tanzania shillings fixed per month. The same applies to guides; the salary with the alternative employment is 700,000 Tanzanian shillings fixed per month. Kimes and Robson, (2004)commented that an employee can get higher income sometimes when the payment system is based on work done (Piece rate wage system). This is influenced by the effort that a person will exert to do more tasks as one can. The ranges with respect to the effort and work done compared to monthly payment system (Rynes et al., 2004). Guides are paid according to a trip and number of days spent in a trip. The higher the number of days spent in a trip the higher the earning and vice versa.

\title{
Engaging in Small Businesses and Entrepreneurial Activities
}

Most of porters and mountain guides were practicing entrepreneurship even before COVID-19 pandemic and after COVID-19 pandemic outbreak that made the tourism industry shut down, they increased entrepreneurial activities to make a living. They were having small business such as retails shops selling home basic needed items like food items, selling second hand clothes, others are food vendors, saloons and barbershops and hiking gears renting and gift shops. Others were brokers of lands, products, houses, cars and minerals. This has been of the successful strategy that has made them to sustain the COVID-19 pandemic economic impacts in tourism industry. They have been doing this in areas such Arusha and Kilimanjaro region where most of these porters and guides inhabit.

\begin{abstract}
"I have my retail shop at Moshi Municipal, whenever I go short of money from mountain climbing activity, the earning from the shops helps me to cover the family needs. The shop has helped me through the COVID-19 pandemic period. But before COVID-19 pandemic I used the earning from my shop for development projects in my family. For instance, I built my house from this retail shop."
\end{abstract}

Before COVID-19 pandemic when they were so busy with mountain climbing expedition, their businesses were managed and looked after by their other family members particularly wives, but after the pandemic that left them jobless, they are currently co-managing business that brings effectiveness. Some have innovated and expanded the businesses and they get high earning that make not to think of returning back to tourism industry in the future when the industry is reopened. Nikolova, (2019) commented that self-employment is paying higher than when you are employed by somebody else. The investment you put, the efforts, creativity and innovativeness can determine the profit which is the residual left after covering all expenses of production (Schummer et al., 2019). But the major problem is the dynamism of the business environment that makes the profit not to be guaranteed.

\section{Conclusion and Recommendations}

The study sought to explore strategies that and techniques that tour guides and porters from Kilimanjaro mountain have managed to survive amidst COVID-19 impact particularly in tourism industry that has caused the shutdown of the industry and cutting off jobs. COVID-19 has affected much negatively the tourism industry specifically to individual who depend on tourism to a make a living. Mount Kilimanjaro porters and guides are the one mostly affected by the pandemic as they depended much on mountain climbing activities as their source of revenue for living. The major economic impact of COVID-19 revealed in this study is the reduction in individual and incomes. It was due to the fact that there was total shut down of the industry and all jobs relating to mountain climbing were 
cut off. From the porters and guides interview the aspects like having personal serving, gifts and grants from once served tourists, subsistence allowances from employers and engaging in other revenue generating activities emerged as the strategies that porters and guides used to survive and sustain in the difficult period of COVID-19 pandemic. According to the study, other income generating activities they engaged in included small businesses and entrepreneurship, looking for alternative employment, engaging in subsistence farming and engaging in sedentary livestock keeping. One of the major problems revealed that made them suffer from COVID-19 pandemic economic impact is that their employments are not permanent and pensionable and the payment is based in work performed (numbers of days spent in a trip). The study recommends the following:

One, those who are working in fragile industries that can easily be affected by uncertainties such as tourism industry should have the saving habit, saving part of what they are earning from the industry. This will help them survival for a certain period of time when the industry faces any challenge that can make activities stop for a while. They can do so by having saving accounts in banks, or saving through SACCOSS and any other means that can be proved to be efficient. But also, the responsible authorities such as Kilimnjaro National Parks (KINAPA) Porters associations, and tour guides association should provide education and capacity building seminars to guides and porters to improve their financial management and investment skills. This will help them think of having other investments that will create extra income instead of depending on mountain hiking activities.

Two, laws should be enacted by the government to recognize and ensure that porters and guides employment positions are to be permanent and pensionable. That they should be paid monthly but also pensions and health insurances should be ensured. This will help them in-case of any challenge in the industry, they can still be sure of getting the basic needs for their family.

\section{Research Limitations and Future Directions}

The study employed qualitative approach so as to get deeper information about strategies used by porters and guides to survive in the difficult time of COVID-19 (Fainshmidt et al., 2020), however the quantitative approach could be used to measure the magnitude of the strategies employed to survive the economic impact of COVID-19 that faced porters and guides. The study focused much on porters and guides but it could also be extended to other workers found in other subsectors of tourism and hospitality industry such as accommodation and transport. Future studies may concentrate much on developing uncertainties response and survival frame work or model that can be applied by workers particularly in tourism industry in case of any uncertainty that may cause negative economic impacts and can cut off their jobs.

\section{References}

Abbas, J., Mubeen, R., Iorember, P. T., Raza, S., \& Mamirkulova, G. (2021). Exploring the impact of COVID-19 on tourism: transformational potential and implications for a sustainable recovery of the travel and leisure industry. Current Research in Behavioral Sciences, 2(1)

Aizenman, J., Cavallo, E., \& Noy, I. (2015). Precautionary Strategies and Household Saving. Open Economies Review, Springer, 26(5), 911-939.

Burlingame, B., Vogliano, C., \& Eme, P. E. (2019). "Leveraging agricultural biodiversity for sustainable diets, highlighting Pacific Small Island Developing States", David B, 
(Ed) \& Jessica, F. (Ed), Advances in Food Security and Sustainability, Elsevier, 4(1), 133-173.

Cleth, C. (2015). Assessment of the challenges facing tour guides and porters: a case of Kilimanjaro National Park. Dodoma. Student's dissertation submitted to The University of Dodoma.

Costa, J., Montenegro, M. and Gomes, J. (2018), "What challenges and opportunities will lead to success?"Worldwide Hospitality and Tourism Themes, 10(6), 631-634.

Deb, S. K., \& Nafi, S. M. (2021). Impact of COVID-19 pandemic on tourism: Recovery proposal for future tourism. Geojournal of Tourism and Geosites, 33(4), 1486-1492.

Fainshmidt, S., Witt, M. A., Aguilera, R. V., \& Verbeke, A. (2020). The contributions of qualitative comparative analysis (QCA) to international business research. Journal of International Business Studies, 51(1), 455-466.

Foo, L., Chin, M., Tan, K., Phuah, K., Chin, M., \& Tan, K. (2020a). The impact of COVID-19 on tourism industry in Malaysia. Current Issues in Tourism, O(0), 1-5.

Francis Mugisha, J., \& Mwende Kajungu, T. (2015). Role of Remuneration in Retention of Health Workforce in a Rural District Setting in Uganda, International Journal of Public Health Research, 3(1), 10-16.

Frolova, E. A. (2019). Trends and problems of development of the world tourism. Vestnik Universiteta.

Galak, J., Givi, J., \& Williams, E. F. (2016). Why Certain Gifts Are Great to Give but Not to Get: A Framework for Understanding Errors in Gift Giving. Current Directions in Psychological Science, 25(6).

Gil-Alana, L. A., \& Poza, C. (2020). The impact of COVID-19 on the Spanish tourism sector. Tourism Economics.

Graeub, B. E., Chappell, M. J., Wittman, H., Ledermann, S., Kerr, R. B., \& GemmillHerren, B. (2016). The State of Family Farms in the World. World Development, 87(1), 1-15

Grobelna, A., \& Skrzeszewska, K. (2019). Seasonality: Is it a Problem or Challenge Facing Future Tourism Employment? Implications for Management. Journal of Entrepreneurship, Management and Innovation, 15(1), 205-230.

Hafsa, S. (2020). Impacts of COVID-19 Pandemic on Tourism \& Hospitality Industry in Bangladesh, SSRN Electronic Journal, available at SSRN; https://ssrn.com/abstract $=3659196$

Horaira, M. A. (2021) Impact of COVID-19 Pandemic on Tourism Industry: Possible Reconciliation Strategy for Bangladeshi Tourism Industry. International Tourism and Hospitality Journal 4(4), 1-17

Kang, S. (2021). Surviving The Impact of COVID-19: '2020 worst year ever' in aviation history,The Edge Markets. Edge Weekly review,

Kasese, F. (2019). An Evaluation of the Challenges Faced by the Tourism and Hospitality Industry in Zimbabwe: A Case Study of Regency Flamboyant Hotel from 2005-2009. The International Journal of Business \& Management, 7(7).

Krieger, A., Block, J., \& Stuetzer, M. (2018). Skill variety in entrepreneurship: A literature review and research directions. International Review of Entrepreneurship, 16(1), 2962.

Kunwar, B. B. (2021). The Impact of COVID-19 on Tourism: A Case Study of Lumbini, Nepal. The Gaze: Journal of Tourism and Hospitality, 12(1), 23-43

Kvirkvelia, N., \& Tsitsagi, M. (2021). Impact of Covid-19 on tourism in georgia-an overview. georgian geographical journal, 1(1). 
Madani, A., Boutebal, S. E., Benhamida, H., \& Bryant, C. R. (2020). The impact of COVID-19 outbreak on the tourism needs of the Algerian population. Sustainability, 12(21), 1-11.

Melubo, K. (2015). The working conditions of Wagumu (high altitude porters) on Mt Kilimanjaro, Mountaineering Tourism.

Melubo, K., \& Buzinde, C. N. (2016). An exploration of tourism related labour conditions: the case of tour guides in Tanzania. Anatolia, 27(4), 505-514.

Melubo, K., \& Kisasembe, R. (2020). We Need Chinese Tourists, but are We Ready? Insights from the Tanzanian Safari Industry. Journal of China Tourism Research, 16(4).

Mwamwaja, E. E. \& Mlozi, S. (2020). An Assessment of the Impact of COVID-19 Pandemic in the Tourism Sector in Tanzania. International Tourism and Hospitality Journal, 3(4), 1-15.

Nikolova, M. (2019). Switching to self-employment can be good for your health. Journal of Business Venturing, 34(4), 664-691.

Noorashid, N., \& Chin, W. L. (2021). Coping with COVID-19: The resilience and transformation of community-based tourism in brunei darussalam. Sustainability, 13(15).

Nyaruwata, S., \& Mbasera, M. A (2021) Critique of Contribution of Tourism to Jobs in Southern African Development Community (SADC): Implications for Post COVID19 Pandemic. International Tourism and Hospitality Journal 4(5), 1-18

Peaty, D. (2010). Kilimanjaro Tourism and What It Means for Local Porters and for the Local Environment, 4(1), 1-11.

Potì, V., Pattitoni, P., \& Petracci, B. (2020). Precautionary motives for private firms' cash holdings. International Review of Economics and Finance. Elsevier, 68(C), 150-166.

Rogerson, C. M., \& Rogerson, J. M. (2020). Covid-19 tourism impacts in south africa : government and industry responses. Geojournal of Tourism and Geositesm, 31(3), 1083-1091.

Rwigema, P. C. (2020). Impact of Covid-19 pandemic to Meetings, Incentives, Conferences and Exhibitions (MICE) tourism in Rwanda. The Strategic Journal of Business \& Change Management, 7(3), 395 - 409.

Rynes, S. L., Gerhart, B., \& Minette, K. A. (2004). The importance of pay in employee motivation: Discrepancies between what people say and what they do. Human Resource Management, 43(4):381 - 394.

Schummer, S. E., Otto, K., Hünefeld, L., \& Kottwitz, M. U. (2019). The role of need satisfaction for solo self-employed individuals' vs. employer entrepreneurs' affective commitment towards their own businesses. Journal of Global Entrepreneurship Research, 9(63).

Shah, C., Chowdhury, A., \& Gupta, V. (2021). Impact of COVID-19 on tourism and hospitality students' perceptions of career opportunities and future prospects in India. Journal of Teaching in Travel and Tourism, 21(2).

Sharma, G. D., Thomas, A., \& Paul, J. (2021). Reviving tourism industry post-COVID-19: A resilience-based framework. Tourism Management Perspectives, 37(1).

Shivakoti, A. (2021). Impact of COVID-19 on Tourism in Nepal. The Gaze: Journal of Tourism and Hospitality, 12(1).

Smart, K., Ma, E., Qu, H., \& Ding, L. (2021). COVID-19 impacts, coping strategies, and management reflection: A lodging industry case. International Journal of Hospitality Management, 94(1). 
Sofronov, B. (2018). The Development Of The Travel And Tourism Industry In The World,"Annals of Spiru Haret University, Economic Series, Universitatea Spiru Haret, 18(4), 123-137.

Soini, E. (2005). Changing livelihoods on the slopes of Mt. Kilimanjaro, Tanzania: Challenges and opportunities in the Chagga homegarden system. Agroforestry Systems, 64(1), 157-167.

Tiwari, P., Séraphin, H., \& Chowdhary, N. R. (2020). Impacts of COVID-19 on tourism education: analysis and perspectives. Journal of Teaching in Travel and Tourism, 20(4), 237-401.

Tovmasyan, G. (2019). Assessment of tourist satisfaction index: evidence from Armenia. Marketing and Management of Innovations. 3(1), 22-32.

Ulak, N. (2020). COVID-19 Pandemic and its Impact on Tourism Industry in Nepal. Journal of Tourism \& Adventure, 3(1), 50-75.

Weber, K. T., \& Horst, S. (2011). Desertification and livestock grazing: The roles of sedentarization, mobility and rest. In Pastoralism, 19(1).

World Tourism Organization. (2020). International Tourist Numbers Could Fall 60-80\% in 2020, UNWTO Reports

WTTC. (2020). WTTC now estimates over 100 million jobs losses in the Travel \& Tourism sector and alerts G20 countries to the scale of the crisis. World Travel and Tourism Council.

Yang, Y., Altschuler, B., Liang, Z., \& Li, X. (Robert). (2020). Monitoring the global COVID-19 impact on tourism: The COVID19tourism index. Annals of Tourism Research.

Yuniti, I. G. A. D., Sasmita, N., Komara, L. L., Purba, J. H., \& Pandawani, N. P. (2020). The impact of COVID-19 on community life in the province of Bali, Indonesia. International Journal of Psychosocial Rehabilitation, 24(10). 